Initial Public Offering and Financing of Biotechnology Start-ups: Evidence from J apan

\author{
Yuji Honjo \\ Sadao Nagaoka
}

IIR Working Paper WP\#15-20

Sep. 2015

Institute of Innovation Research

Hitotsubashi University

Tokyo, Japan

http://www.iir.hit-u.ac.jp 



\title{
Initial public offering and financing of biotechnology start-ups: evidence from Japan*
}

\author{
Yuji Honjo ${ }^{\dagger}$ and Sadao Nagaoka ${ }^{\ddagger}$
}

\begin{abstract}
This paper explores the initial public offering (IPO) and financing of biotechnology start-ups in Japan. Using a unique data set, we find that biotechnology start-ups initially backed by venture capital (VC) firms and those originating from universities are more likely to go public within a shorter period. Moreover, we examine whether two investment methods used by VC firms - staged financing and syndication - affect the market value of equity at the IPO. The results reveal that these methods do not create a higher value of biotechnology start-ups at the IPO. Furthermore, we provide evidence that the timing of IPOs does not depend on market conditions in the biotechnology industry, whereas the market value of equity tends to depend on market conditions.
\end{abstract}

JEL Classifications: G32; M13; L65

Keywords: Biotechnology; Initial public offering; Market value; Staged financing; Start-up; Syndication

\footnotetext{
${ }^{*}$ This study is part of an extended project of a research program entitled "Research on Science Sources of Innovations and Economic Impacts of Science" supported by the Japan Science and Technology Agency. We are grateful to the participants of the workshop held at Hitotsubashi University and Nagoya University. In particular, we thank Takanori Adachi, Yoshiaki Ishii, Daisuke Miyakawa, and the members of our research project for their valuable comments and suggestions. Moreover, we would like to express our appreciation to the directors of biotechnology start-ups and venture capitalists who agree to participate in our interviews. Needless to say, any remaining errors are the authors' own.

${ }^{\dagger}$ Y. Honjo (corresponding author)

742-1 Higashinakano, Hachioji, Tokyo 192-0393, Japan

Faculty of Commerce, Chuo University

e-mail: yhonjo@tamacc.chuo-u.ac.jp

${ }^{\ddagger}$ S. Nagaoka

Faculty of Economics, Tokyo Keizai University
} 


\section{Introduction}

The emergence of new technologies is believed to spur future economic growth. Among the new technologies, biotechnology has created a paradigm shift in the pharmaceutical and agricultural fields. For instance, in accordance with the recent development of biotechnology, the major drug discovery approach seems to have shifted from chemical-based to biotechnology-based ones. ${ }^{1}$ Such a paradigm shift may have a considerable impact on industrial organization in the pharmaceutical industry. Indeed, until recently, large pharmaceutical companies have been central to drug discovery, including the so-called "blockbuster." ${ }^{2}$ However, the division of labor between biotechnology start-ups, universities, and pharmaceutical companies has become more important because the drug discovery process is highly uncertain and includes multiple stages. Compared with large pharmaceutical companies, small, young firms and universities as a whole can undertake more discovery projects and therefore are expected to play an important role in providing new drug candidates and drug discovery technologies. Large pharmaceutical companies may often use alliances with universities and biotechnology start-ups for drug discovery. At the same time, the division of labor enables large pharmaceutical companies to reduce the high risk in the early-stages of drug development by aligning with biotechnology start-ups, although the risks are ultimately born in private equity markets.

As biotechnology start-ups require a large amount of research and development (R\&D) investment, they must often rely on external finance. However, biotechnology start-ups cannot always obtain sufficient funds from loans because of uncertainty

\footnotetext{
${ }^{1}$ Among the best-selling drugs of 2013 , for example, seven drugs derived from biotechnologyadalimumab (Humira ${ }^{\circledR}$ ) [Rank 1], etanercept (Enbrel ${ }^{\circledR}$ ) [Rank 2], infliximab (Remicade ${ }^{\circledR}$ ) [Rank 3], rituximab (Rituxan ${ }^{\circledR}$ ) [Rank 6], bevacizumab (Avastin ${ }^{\circledR}$ ) [Rank 7], and trastuzumab (Herceptin ${ }^{\circledR}$ ) [Rank 9]-are ranked in the top 10 for worldwide sales. For more details, see the website of Free Daily Pharma Industry Newsletter.

http://www.fiercepharma.com/special-reports/top-10-pharma-companies-2013-revenue [accessed on February 17, 2015].

${ }^{2}$ The large pharmaceutical companies in Japan, such as Takeda Pharmaceutical, have developed some chemical blockbusters; for example, candesartan (Blopress ${ }^{\circledR}$ ). As Kneller (2003) stated, drug discovery in the Japanese pharmaceutical companies has occurred predominantly in-house.
} 
and information asymmetries between entrepreneurs and creditors. To facilitate equity financing of $\mathrm{R} \& \mathrm{D}$, biotechnology start-ups tend to pursue greater access to equity markets. Although not all do this, some biotechnology start-ups go public; that is, they issue an initial public offering (IPO). In particular, biotechnology start-ups that require a significant amount of funds for R\&D are compelled to go public for conducting $R \& D$ activities. The fate of their $R \& D$ activities is critically dependent on whether such biotechnology start-ups can go public. In this case, we have a saying: "public or perish."

This paper explores the IPO and financing of biotechnology start-ups in Japan. Despite the important role of small and young firms, biotechnology start-ups appear to be inactive in the Japanese economy. In this respect, the investigation of biotechnology start-ups would be of great interest in promoting the development of the biotechnology industry. To our understanding, however, there is a scarcity of data suitable for empirical studies. In this paper, we construct a unique data set of 213 firms that were founded in the most recent twenty-year period (1995-2014).

This paper aims to investigate the market values of equity for biotechnology start-ups at the IPO. This is because most initial investors, including venture capital (VC) firms, presumably pay much attention to these issues. However, many biotechnology start-ups remain privately held. Before doing so, therefore, we examine the types of biotechnology start-ups that go public. Using a survival analysis approach, we find that biotechnology start-ups initially backed by $\mathrm{VC}$ firms and those originating from universities are more likely to go public within a shorter period. With respect to the market values of equity, the results reveal that two investment methods often regarded to be value enhancing-staged financing and syndication - do not create a higher value of biotechnology start-ups at the IPO. Furthermore, we provide evidence that the timing of IPOs does not depend on market conditions in the biotechnology industry, whereas the market value of equity tends to depend on market conditions. 
The remainder of this paper is organized as follows. The following section introduces the research background, including a review of the relevant literature. Section 3 describes the method used in this paper. Section 4 explains the data used in our analysis, and Section 5 presents the estimation results. In the final section, we provide some concluding remarks.

\section{Research background}

\subsection{IPOs of biotechnology start-ups}

For high-tech start-ups, financing becomes a critical factor in expanding their businesses. Even if a firm has growth potential, external suppliers of capital - such as banks and investors - do not always provide sufficient capital to the firm. This is because these suppliers cannot completely understand new technologies the firm is developing; that is, information asymmetries arise between entrepreneurs and external suppliers of capital. In particular, younger firms face more difficulties in raising funds from external suppliers of capital as they have limited operating histories and lack complementary assets, including know-how and relationships that take many years to develop.

High-tech start-ups, including biotechnology start-ups, tend to require external financing for a large amount of R\&D investment. However, banks are often reluctant to lend money to high-tech start-ups because R\&D investment is likely to become sunk costs and high-tech start-ups have few tangible assets to provide sufficient collateral. Moreover, many start-ups do not generate cash flow during their start-up period; thus, debt-financing interest payments become a burden on their businesses. In this respect, high-tech start-ups are more likely to rely on equity financing rather than debt financing, such as bank loans.

It is often argued that venture capitalists play a critical role in providing funds to high-tech start-ups. As Gompers (1995) emphasized, venture capitalists concentrate 
investments in younger firms and high-tech industries where informational asymmetries are significant and monitoring is valuable. The role of venture capitalists may be important for high-tech start-ups, especially in countries such as Japan, where private financings that raise funds from individual investors are less common. ${ }^{3}$ At the same time, venture capitalists seek exit strategies for their investments and, without doubt, an IPO is one of their most typical exit strategies. While an IPO is simply one of the millstones for biotechnology start-ups in the process of technology and product development, investors - including venture capitalists - expect larger capital gains from an IPO. More importantly, because mergers and acquisitions $(\mathrm{M} \& \mathrm{~A})$ are less pronounced as a strategic exit in Japan, venture capitalists are more likely to rely on an IPO as an exit strategy. Therefore, to recoup their investments and proceed to invest in another high-tech start-up, venture capitalists expect the start-ups to conduct an IPO in a relatively short timeframe.

Many studies have emphasized the role of VC on the IPO process. Megginson and Weiss (1991), for example, found that VC-backed firms are significantly younger, have greater median book values of assets, and have a larger percentage of equity in the capital structure than their non-VC-backed counterparts. Helwege and Packer (2009) argued that firms controlled by VC and private equity specialists are significantly more likely to go public and that these firms value the IPO as an important exit strategy for outside equity. Therefore, it is plausible that the likelihood of an IPO depends on the presence of VC.

Regarding the IPO of biotechnology firms, Lerner (1994b) examined the timing of IPOs and private financings by venture capitalists. ${ }^{4}$ Using a sample of 350 privately held VC-backed biotechnology firms in the US between 1978 and 1992,

\footnotetext{
${ }^{3}$ In fact, as shown later, more than $20 \%$ of IPO firms in our data set relied on VC firms for their initial financing.

${ }^{4}$ Although they did not focus on biotechnology firms, Pagano et al. (1998) estimated the determinants of IPOs using a database of private firms in Italy and found that the likelihood of an IPO is increasing in firm size and the industry's market-to-book ratio. More recently, several empirical studies have examined the likelihood of an IPO using data on firms in Japan (e.g., Honjo, 2012; Miyakawa and Takizawa, 2013).
} 
Lerner showed that these firms go public when equity values are high, and that they employ private financings when equity values are lower. The results indicated that the likelihood of an IPO for biotechnology start-ups depends on market conditions. However, financing is often critical for most biotechnology start-ups because they must continue to support $R \& D$ activities that require a large amount of investment. In particular, biotechnology start-ups that face financial difficulties in conducting $\mathrm{R} \& \mathrm{D}$ activities cannot afford to wait for a market recovery, even though they hope that market conditions steadily improve. Therefore, there is the possibility that biotechnology start-ups tend to go public, regardless of market conditions. Rather, biotechnology start-ups may prefer to go public within a shorter period to expand their equity financing of $R \& D$ activities. At the same time, this may result in the recovery of investments for initial investors.

As mentioned earlier, this paper explores the IPO of biotechnology start-ups in Japan. Whereas Lerner's (1994b) results indicate the impact of market conditions on the likelihood of an IPO, biotechnology start-ups may go public, regardless of market conditions, to secure financing for their R\&D activities. Venture capitalists - some of whom play a critical role as initial investors in Japan where private financings through individual investors (the so-called "business angels") are less common - also hope to quickly recoup their investments. ${ }^{5}$ Therefore, we predict that biotechnology start-ups that are initially financed by VC firms are more likely to go public within a shorter period.

\subsection{IPO values of biotechnology start-ups}

Most, but not all, high-tech start-ups expect to raise funds from capital markets through an IPO. High-tech start-ups often require financing because of a large

\footnotetext{
${ }^{5}$ For instance, using data provided by the Global Entrepreneurship Monitor, Honjo (2015) found that among 32 countries, Japan has the lowest level for new business investment by individuals, as measured by the ratio of individuals who have personally provided funds for a new business started by someone else in the three years.
} 
amount of capital for R\&D activities. By analyzing data on Italian firms, Pagano et al. (1998) estimated the effects of an IPO on firm performance based on accounting measures, such as the return on assets (ROA) and capital expenditures. ${ }^{6}$ However, we cannot say that current profitability is a better index of short-term performance for biotechnology start-ups. This is because most biotechnology start-ups remain in the R\&D phase, even after going public, and they do not gain sufficient sales and yield positive profits. Meanwhile, initial investors would probably pay more attention to recouping their investments. Regarding the success of an IPO, Deeds et al. (1997) addressed the amount of capital raised by the firm. If access to capital is the major goal of going public, the amount of capital raised from the market will generate interest among initial investors, including venture capitalists.

To date, several studies have examined the IPO value, which indicates the market value of equity at the IPO, and the determinants of the IPO value. By analyzing data on 92 publicly-held firms in the US biotechnology industry, Deeds et al. (1997) defined the IPO value as the total value of capital raised from the IPO minus the underwriter's fees and estimated the effects of location, the number of products, and citations on the IPO value. Based on 36 firms in the Korean biotechnology industry, Lee and Lee (2008) also used a similar variable for the IPO value and found the effects of R\&D investment, sales, and profits on the IPO value. Whereas these studies provided interesting results, their results may simply reflect the characteristics of biotechnology firms with a large capital size. Initial investors, including venture capitalists, often invest a large amount of capital leading up to the IPO. Even if the value of a firm is evaluated as high at the IPO, there is the possibility that this value does not generate sufficient returns for investors. From the viewpoint of investors, therefore, more attention should be paid to the return on investment; that is, we should address how the IPO yields a return from the invested capital prior to the

\footnotetext{
${ }^{6}$ As for IPOs in Japan, Miyakawa and Takizawa (2013) investigated firm performance measured by total factor productivity and ROA, using a difference-in-difference approach.
} 
IPO.

This paper investigates the IPO value of biotechnology start-ups. When measuring this value, we use not only the market value of equity at the IPO but also a relative measure for the IPO value from the perspective of investment efficiency. Furthermore, some biotechnology start-ups reduce their equity prior to the IPO to eliminate any accumulated deficits. As total equity at the time of the IPO does not include capital reductions, it is inappropriate to capture the amount of total investment, which is used as the denominator when we assess the IPO value. In this paper, therefore, we propose a new proxy for firm performance at the IPO, taking into account capital reductions. ${ }^{7}$

\subsection{Investment methods of VC firms}

VC firms must address information uncertainty associated with investment decisions and information asymmetries between entrepreneurs and venture capitalists, which often generate agency and monitoring costs. To reduce information uncertainty and asymmetries, venture capitalists often utilize staged capital infusion; namely, "staged financing." As Gompers (1995) argued, staged capital infusion enables venture capitalists to reevaluate the firm's project and to reduce potential losses from bad decisions. Gompers also provided evidence on the positive relationship between total $\mathrm{VC}$ financing and the number of financing rounds. ${ }^{8}$

In addition to staged financing, syndication is a widely-used method for the investment strategy of VC firms. VC firms utilize syndication when they jointly invest in a firm, while undertaking staged financing. As Lerner (1994a) argued, syndication is a mechanism through which venture capitalists resolve the informa-

\footnotetext{
${ }^{7}$ Nelson (2003) also proposed an index for the percent price premium at the IPO, which indicates the assessment of investor optimism. Meanwhile, the cumulative average market-adjusted return and average buy-and-hold return for the post-IPO have often been used. In this paper, however, we highlight performance at the IPO, rather than after the IPO, and do not employ these measures. Further investigation of these measures will be part of our future studies.

${ }^{8}$ Hand (2007) found that equity returns between financing rounds are reliably negatively related to firm size and positively related to book-to-market ratios.
} 
tional uncertainty about potential investments. Lerner emphasized that syndication leads to a superior selection of investments, which is referred to as the "selection hypothesis," and provided support for this hypothesis using data on VC investments in the biotechnology industry. Because it is more efficient to undertake the projects approved by two or more reviewers (investors) during the staged financing process, syndication may enhance the market value of equity at the IPO. Lerner also examined the choice of syndication partners in first, second, and later rounds, and found that in the first round, established venture capitalists tend to syndicate with one another; however, later rounds involve less established venture organizations. This indicates that syndication in the first round of financing leads to better decisions about whether to invest because informational asymmetries are more severe. Therefore, this stage plays a more significant role in increasing the market value of the firm compared with syndication in the later rounds of financing. In this respect, we can say that the effects of syndication differ between the first and later rounds of financing.

In contrast, Brander et al. (2002) argued that returns to syndicated investments are lower than those to standalone investments. ${ }^{9}$ If the assessment by a venture capitalist yields a high expected value, the venture capitalist accepts the project as there is little need for syndication. Similarly, there is little need for staged capital infusion in this case. Therefore, it is possible that staged capital infusion and syndication induce a negative signal about the project. Meanwhile, VC firms have a strong incentive to participate in syndicated investment in firms with a higher probability of issuing an IPO. This is because investing in IPO firms enables VC firms to enhance their reputation in the market. As a result, VC firms are reluctant to miss any investment opportunities in IPOs and, hence, they have an incentive to

\footnotetext{
${ }^{9}$ Brander et al. (2002) proposed the additional role of syndication, which is referred to as the "value-added hypothesis," because venture capitalists can add value to the firms in which they invest, and addressed the value-added hypothesis over the selection hypothesis as a possible rationale for syndication.
} 
participate in syndicated IPO investments, regardless of the expected value of the projects.

In this paper, we highlight these investment methods of venture capitalists. As discussed above, it is unclear whether these methods really generate a higher value for an IPO. Furthermore, it is well recognized that Japan has the characteristics of a bank-centered capital market (e.g., Black and Gilson, 1998). In fact, many VC firms in Japan originated as subsidiaries of financial institutions, including banks and security companies, where some managers are on temporary assignment. These VC firms have an incentive to safely manage the assets provided by their parent companies rather than to take large risks, thereby resulting in an increase in the number of $\mathrm{VC}$ firms that imitate such investment behavior. This paper examines whether these investment methods add values to the Japanese biotechnology start-ups.

\section{Method}

\subsection{IPO duration}

First, using a survival analysis approach, we investigate the types of firms that go public within a shorter period. Consider the probability of firm $i$ 's IPO at $t$, which indicates the duration from the foundation date to the IPO date (hereafter, "IPO duration"). Let $T_{i}^{*}$ denote the IPO duration of firm $i$. However, we cannot observe $T_{i}^{*}$ for all firms because many firms have not yet gone public during the observation period. Furthermore, while some firms go public during the observation period, others exit the market before going public because of liquidation through bankruptcy. More precisely, $T_{i}^{*}$ is observable if a firm goes public until censoring time, denoted by $C_{i}$, and the firm does not exit the market before going public; otherwise, $T_{i}^{*}$ is not observable. We can define observable time, $T_{i}$, such that $T_{i}=$ $\min \left\{T_{i}^{*}, \tilde{T}_{i}, C_{i}\right\}$ where $\tilde{T}_{i}$ is a competing event other than an IPO.

The probability of firm $i$ 's IPO is captured by a hazard, $h\left(t ; Z_{i t}\right)$, which is a 
function of a vector of covariates (variables), $Z_{i t}$. Based on this hazard, we consider a proportional hazards model proposed by Cox (1972) to identify the determinants of an event. However, some firms exit the market before going public because of liquidations. Without considering these exits, we would produce results with a selection bias. Therefore, we regard exits as competing risks and estimate the determinants of IPOs other than exits. ${ }^{10}$

Instead of the standard proportional hazards model, we employ a competingrisks regression and define the sub-hazard, $\bar{h}\left(t ; Z_{i t}\right) .{ }^{11}$ The specification, which is similar to the proportional hazards model, is write as follows: ${ }^{12}$

$$
\bar{h}\left(t ; Z_{i t}\right)=\bar{h}_{0}(t) \exp \left(\alpha Z_{i t}\right)
$$

where $\bar{h}_{0}(t)$ is the baseline sub-hazard and $\alpha$ is the parameter to be estimated. By maximizing the log-pseudo-likelihood function proposed by Fine and Gray (1999), we obtain the parameter estimates, $\hat{\alpha}$, which indicate whether the covariate shortens the duration of an IPO.

Note that the IPO duration denoted by $t$ indicates firm age at the IPO. According to their foundation years, firms face different market conditions; therefore, we control for market conditions in the estimation.

\subsection{IPO values}

Next, we investigate firm performance measured by the market value of equity at the IPO, based on a cross-sectional analysis. As we cannot observe the market values for privately-held firms, we estimate the determinants of the IPO values only for firms

\footnotetext{
${ }^{10}$ In practice, several firms acquired by public firms might achieve a successful exit strategy. Unfortunately, we could not identify which firm achieved a successful exit in the data set; thus, we treat exits other than IPOs as competing risks. However, as M\&A are less pronounced as an exit strategy in Japan, it is considered that successful exits are rare.

${ }^{11}$ Meanwhile, Giot and Schwienbacher (2007) examined the time-to-exit through an IPO, a trade sale, and a liquidation for VC-backed firms, using a sample of investment rounds. In their estimation, a competing-risks regression was used to allow for a joint analysis of exit type and exit timing.

${ }^{12}$ For more details on the competing-risks regression, see, for example, Fine and Gray (1999).
} 
that have gone public during the observation period. In the data set, although many firms are privately held, some firms conduct an IPO. If we find a positive effect of VC firms on the IPO value, then this finding may indicate that the firm backed by VC firms has a higher probability of issuing an IPO. Therefore, we employ a sample selection model, while taking into account the sample selection bias,.

Let $Y_{i}$ denote the market value of equity for firm $i$ at the IPO. We assume that this market value is a linear function of a vector of variables, $X_{i}$. Hence, we write this as follows:

$$
Y_{i}=\beta_{0}+\beta_{1} X_{i}+u_{i}
$$

where $\beta_{0}$ and $\beta_{1}$ are parameters to be estimated; $u_{i}$ is an error term; and $u_{i} \sim$ $N\left(0, \sigma^{2}\right)$. For Equation (2), however, $Y_{i}$ can be observed if

$$
\gamma_{0}+\gamma_{1} W_{i}+v_{i}>0
$$

where $W_{i}$ is a vector of variables; $\gamma_{0}$ and $\gamma_{1}$ are parameters to be estimated; $v_{i}$ is an error term; $v_{i} \sim N\left(0,1^{2}\right) ; u_{i}$ and $v_{i}$ have correlation $\rho$; and $\lambda=\rho \sigma$. Otherwise, $Y_{i}$ cannot be observed.

A two-step estimation method proposed by Heckman (1979) —often called the "Heckman selection model" - is used to obtain the parameter estimates: $\hat{\beta}_{0}, \hat{\beta}_{1}, \hat{\gamma}_{0}$, and $\hat{\gamma}_{1} \cdot{ }^{13}$ In Equation (2), we regress $Y_{i}$ on $X_{i}$, while estimating parameters $\rho$ and $\sigma$. Among the parameter estimates, $\hat{\beta}_{1}$ indicates whether the variable affects the market value of equity for biotechnology start-ups.

\section{Data}

\subsection{Data source}

When examining start-up firms in Japan, we often face difficulties in obtaining data and developing cases suitable for our studies. For instance, although the Nikkei Economic Electronic Databank System-Financial Quest (NEEDS-FQ), which has often

\footnotetext{
${ }^{13}$ We employed the maximum likelihood estimation, instead of the Heckman two-step estimation.
} 
been used as a data source for Japanese firms, covers all listed firms in Japan, the it does not sufficiently cover small and young firms. Moreover, the database provided by a credit investigation company, such as Teikoku Data Bank, does not include an industrial classification for biotechnology and, therefore, it is quite difficult to collect data on biotechnology firms. How we construct a data set of biotechnology start-ups under these constraints is critical in conducting research on biotechnology start-ups in Japan.

To construct the data set of biotechnology start-ups, we obtained a list of firms from the Japan Bioindustry Association (JBA), which is a general incorporated foundation that promotes the development of the biotechnology industry and that surveys biotechnology firms in Japan. ${ }^{14}$ However, since the JBA does not usually survey the financing of biotechnology firms, especially from venture capitalists, we cannot identify how biotechnology firms are financed and which ones are backed by VC firms from this data source. For this reason, we collected data on the financing of biotechnology firms from a database provided by Japan Venture Research (JVR), which is a research and consulting company that surveys not only venture capitalists but also new ventures backed by VC firms or other corporations. As a result, by matching firms listed in the JBA and JVR databases, we constructed a data set of biotechnology start-ups. ${ }^{15}$ In addition to these data sources, the listing prospectus, annual securities report, and website of each firm were used to collect data on the firm's profile. Moreover, Kabushiki Kokai Hakusho (White Paper on Initial Public Offerings) edited by Disclosure Jitsumu Kenkyukai was used to collect data on the timing and capital increases of IPOs. Furthermore, the NEEDS-FQ was used to collect data on stock prices, equity values, and stock market indices.

To determine the observation period, we describe the trend in the number of

\footnotetext{
${ }^{14}$ For more details on the surveys of the JBA, see, for example, Honjo et al. (2014).

${ }^{15}$ We constructed our data set mainly from the JVR database because the required financial data for our analysis were available in the JVR database. A few firms listed in the JVR database were regarded in the JBA database as no longer engaged in biotechnology; thus, these firms were excluded from the data set.
} 
firms in the biotechnology industry of Japan in Figure $1 .{ }^{16}$ We found that the number of firms increased after the mid-1990s, reached its peak in the 2000s, and decreased in recent years. Several firms founded over a long period of time are included in the JVR database. Therefore, we set 20 years as the "start-up" stage and excluded firms that exceeded 20 years from the data set. ${ }^{17}$ More precisely, the data set comprises biotechnology firms founded during the period 1995-2014, which is the observation period in this paper. As shown in Figure 1, this period covers the boom times for new entrants in the biotechnology industry of Japan.

As an additional data screening step, firms of which primary businesses are regarded as contract research organizations (CRO) or site management organizations (SMO) are excluded from the data set. In addition, a few foreign firms of which head offices are located outside Japan are excluded from the data set. As a result, we define a biotechnology start-up as a firm founded during the period 1995-2014 in the biotechnology industry of Japan, except for CRO and SMO.

\subsection{Descriptive statistics}

The data set comprises 213 biotechnology start-ups in Japan. Among them, 33 firms $(33 / 213 \simeq 15 \%)$ have experienced an IPO, while 180 firms have not (to December 2014). ${ }^{18}$

For the 33 IPO firms, Figure 2 displays the trend in the number of IPOs in each market. As shown in Figure 2, all of the IPO firms were not listed in the

\footnotetext{
${ }^{16}$ Figure 1 indicates the number of firms, based on the JBA survey, regardless of age. Moreover, our constructed data set does not include firms if it was unclear whether the firms were backed by VC firms. Therefore, the number of firms in Figure 1 is larger than that in our data set.

${ }^{17}$ In general, the period of 20 years seems rather long as a start-up stage. However, since it often takes a long period to develop new drugs, we employed 20 years as the observation period. Note that the definition of biotechnology start-ups in the JBA survey is not completely consistent with our definition, as the JBA survey excludes young but large-sized firms.

${ }^{18}$ Although three of the 33 firms (LTT Bio-Pharma, ECI, and Mebiopharma) were privately held in December 2014 by going private, we regarded these three firms as IPOs in the analysis. Further, since data on the number of financing rounds, which will be discussed later, were not obtainable for one firm (Mebiopharma) in the JVR database, we employed 32 firms in the analysis of IPO values.
} 
established stock exchanges, such as the Tokyo Stock Exchange (TSE), but in the emerging markets-JASDAQ, MOTHERS, Centrex, and Tokyo Pro Market (formerly, Tokyo AIM) — which provide access to the funding of young and emerging small- and medium-sized firms. This is mainly because there are no criteria for financial performance, such as profits, in some of the emerging markets. Indeed, without these emerging markets, some of the IPO firms would not be able to go public as they have negative profits. ${ }^{19}$ In this respect, we can say that the emerging markets in Japan are helpful in promoting the IPO of biotechnology start-ups.

Surprisingly, IPOs in the biotechnology industry of Japan are consistently found in Figure 2. New emerging markets, such as MOTHERS and Centrex, have been created since the late 1990s and two university-origin start-ups (Anges MG and Trans Genic) went public in 2002. Since then, biotechnology start-ups have continued to issue an IPO in the emerging markets. More importantly, the economic recession triggered by the Lehman Brothers collapse in 2008 resulted in depressed stock markets in Japan. According to Kabushiki Kokai Hakusho, the number of IPOs in all of Japan's stock markets considerably decreased after the Lehman Brothers collapse and this number in all industries was down to fewer than 20 in 2009. Nevertheless, as Figure 2 demonstrates, a dramatic change in the number of IPOs in the biotechnology industry is not found in and after 2009. In this respect, it is plausible that the IPO of biotechnology start-ups is independent of market conditions.

Table 1 presents the trend in the number of biotechnology start-ups founded in each year. While the number of biotechnology start-ups $(A+B)$ increases from the late 1990s to the early 2000s, it decreases after the late 2000s. This trend is consistent with the distribution shown in Figure 1. In this respect, the low level of new entrants in recent years, which indicates stagnant entrepreneurship, is of increasing concern in developing the biotechnology industry of Japan. Meanwhile, while the

\footnotetext{
${ }^{19}$ Among the 32 IPO firms in the data set, 22 firms $(22 / 32 \simeq 69 \%)$ had negative operating profits in their post-IPO accounting year, although the financial statements of one IPO firm (Ribomic), which went public in September 2014, could be obtained.
} 
number of biotechnology-startups $(A+B)$ founded in the late 1990s is lower, the ratio of IPO firms $(A /(A+B))$ seems higher. Some biotechnology start-ups founded in the late 1990s may be able to go public because of the boost in the emerging markets and the policies promoting start-ups from universities. ${ }^{20}$

Table 2 presents the summary statistics of IPO duration, which capture firm age measured by the number of months from the foundation date to the IPO date. The IPO duration for the 33 IPO firms, on average, takes 84 months (7 years), although this value is restricted to biotechnology start-ups that have already gone public. Table 2 also presents the summary statistics of IPO duration for each five-year period, according to the foundation years of firms. While the ratio of IPO firms founded in the late 1990s is higher, as shown in Table 1, the IPO duration does not seem to differ according to the foundation year of firms.

Tables 3 and 4 describe the distribution of biotechnology start-ups by dividing the data set into IPO firms (public firms) and non-IPO firms (private firms). Table 3 presents the number of biotechnology start-ups that raised equity from VC firms when they were founded (hereafter, "initially VC-backed start-ups"). The ratio of initially VC-backed start-ups accounts for more than $20 \%(\simeq 7 / 33)$ of IPO firms in the data set. According to Table 3, while the ratio of initially VC-backed start-ups seems low $(17 / 213 \simeq 8 \%)$, the ratio of IPO firms for initially VC-backed start-ups $(7 / 17 \simeq 41 \%)$ is much higher than that for others $(26 / 196 \simeq 13 \%)$. There is a traditional view that VC firms rarely invest in high-technology firms in Japan (e.g., Black and Gilson, 1998). However, we provide evidence that VC firms play a role in providing funds to biotechnology start-ups, especially as initial investors, partly because equity financing from individual investors is less common in Japan.

Table 4 presents the number of biotechnology start-ups that originated from technologies developed in universities or persons associated with universities (here-

\footnotetext{
${ }^{20}$ In 2001, the Ministry of Economy, Trade and Industry in Japan proposed a policy entitled, "The 1000 University-launched Ventures Plan," to promote an industry-academia-government collaboration.
} 
after, "university-origin start-ups"). While development in science spreads rapidly at the international level, as argued by Goto (2000), universities still play a vital role in their respective countries as a local source of scientific knowledge. In the data set, university-origin start-ups account for approximately $39 \%(\simeq 83 / 213)$ of biotechnology start-ups, suggesting that universities play a role in providing the technological seeds for biotechnology start-ups in Japan. Moreover, the ratio of IPO firms for such university-origin start-ups $(23 / 83 \simeq 28 \%)$ is higher than that for others $(10 / 130 \simeq 8 \%)$. Tables 3 and 4 may also indicate that the likelihood of an IPO depends on the initial conditions for new firm creation.

Table 5 describes the market value of equity for IPO firms in the data set. The mean of the IPO value that indicates the market value of equity at the IPO is approximately 29 billion yen (the median is approximately 14 billion yen). In Table 5 , we present equity financing that includes not only total paid-in capital (paid-in capital plus additional paid-in capital) but also capital reduction. Although capital reduction decreases equity, it should be included in equity financing prior to the IPO. In other words, Table 5 provides "gross" equity financing prior to the IPO by returning capital reduction to equity financing. Moreover, because firms usually issue new equity when they go public, we also provide the "IPO capital increase," which indicates the capital increase at the IPO. Table 5 shows that the mean of equity financing prior to the IPO is approximately 3.6 billion yen (the median is approximately 1.8 billion yen) and the mean of the IPO capital increase is approximately 2.4 billion yen (the median is approximately 2.1 billion yen). Furthermore, Table 5 presents the ratio of the IPO value divided by equity financing prior to the IPO and divided by the total equity invested that is measured as the sum of equity financing prior to the IPO and the capital increase at the IPO. The latter ratio proposed in this paper $(A /(B+C))$ is a useful proxy to capture investment efficiency at the IPO, which may reflect firm performance and is similar to the concept of the market-to-book ratio or average Tobin’s $q$. As a result, we find that a $¥ 1$ 
investment in a biotechnology start-up that goes public provides an average return of $¥ 7.15$ beyond the total equity invested (the median is $¥ 3.05$ ).

Table 6 describes the numbers of financing rounds and VC firms for IPO firms. ${ }^{21}$ We find that biotechnology start-ups in Japan, on average, have experienced approximately five financing rounds and have been financed by approximately $14 \mathrm{VC}$ firms prior to the IPO. Moreover, Table 6 indicates the number of VC firms from the foundation date through the first round of financing (hereafter, "first-round VC firms"), since the effects of syndication on the IPO values differ between the first and later rounds of financing. As shown in Table 6, biotechnology start-ups in Japan, on average, have been financed by approximately three first-round VC firms. Additionally, Table 7 presents the market value and financing of equity for IPO firms, according to the number of financing rounds and first-round VC firms, respectively. Surprisingly, the mean and median of the IPO values are higher for biotechnology start-ups with fewer financing rounds. Likewise, they are higher for those with fewer first-round VC firms. These findings indicate that the IPO values may actually decrease with the frequency of these investment methods, in contrast to previous arguments in studies by Lerner (1994a) and Gompers (1995). We will further investigate whether these methods decrease the IPO values using the regression analysis.

\subsection{Variables}

In this section, we explain the variables (covariates) used in the estimation regressions for the IPO duration and the IPO value. First, we discuss the determinants of the IPO duration, which is observable for all firms in the data set. We examine whether initial involvement affects the IPO duration of biotechnology start-ups. As previously mentioned, it is hypothesized that biotechnology start-ups initially

\footnotetext{
${ }^{21}$ According to the JVR database, a capital increase through a third-party allocation is defined as a financing round. Note that a capital increase through the allocation of VC firms and other corporations is counted, whereas a capital increase only through the allocation of individuals and sole proprietorships is not counted as a financing round. In addition, multiple capital increases within three months are regarded as one financing round.
} 
backed by VC firms are more likely to go public within a shorter period. We use a dummy variable for the initial financing of $\mathrm{VC}$ firms $\left(V C_{-} S T\right)$ to represent the initial involvement. ${ }^{22}$

A dummy variable for university origin $(U N I V)$ is also included in the estimation regression. As is well-known, scientific knowledge is the most important asset of biotechnology start-ups and, as shown in Table 4, approximately $39 \%$ of biotechnology start-ups in the data set originate from universities. We examine whether biotechnology start-ups originating from universities are more likely to go public within a shorter period.

Additionally, a dummy variable for spin-offs (SPINOFF) is used to measure whether the firm is a spin-off and examine the effects of a parent company on the likelihood of an IPO. ${ }^{23}$ Using this variable, we examine whether the IPO of biotechnology start-ups depends on initial involvement. These variables are obtained from the JVR database.

Moreover, the likelihood of an IPO may depend on market conditions, such as "hot issue" markets, when shareholders, including VC firms, expect higher capital gains. The literature on finance has argued that the IPO market exhibits dramatic swings in issuance that are often referred to as hot and cold markets (e.g., Ibbotson and Jaffe, 1975; Ritter, 1984; Helwege and Liang, 2004). To measure market conditions, we use a variable for the JASDAQ index (JINDEX), which is a market capitalization-weighted index provided by the TSE that is based on all domestic

\footnotetext{
${ }^{22}$ How the timing of the financing of $\mathrm{VC}$ firms affects the IPO duration would provide more comprehensive evidence on the role of VC firms. However, we could not obtain data from the JVR database on each individual financing of VC firms for IPO firms and non-IPO firms, except for the initial financing.

${ }^{23}$ In the JVR database, Takara Bio was not regarded as a spin-off. However, since this firm was founded when Takara Shuzo became Takara Holdings, which is the major shareholder of Takara Bio, we regarded this firm as a spin-off. Meanwhile, spin-offs sometimes discriminated from spin-outs, which are not capitalized by their parent companies. As we did not completely distinguish between them and the sample size was not sufficiently large, we included spin-outs in the definition of the variable.
} 
common stocks listed on JASDAQ. ${ }^{24}$ JASDAQ is one of the major emerging markets in Japan and indeed, as shown in Figure 2, some biotechnology start-ups are listed on JASDAQ. ${ }^{25}$ The values of this variable differ across firms, according to the month and year when the firms were founded. While this variable is time variant, the others are time invariant in the estimation regression of IPO duration.

Furthermore, as shown in Table 1, the ratio of IPO firms to total firms may differ according to the foundation year. Therefore, the cohort dummies for the foundation year (C95_99 and C00_04) are included in the estimation regression. ${ }^{26}$ Finally, the industry dummies (DRUG and $H E A L T H)$ are included in the estimation regression.

Next, we discuss the determinants of the IPO values, which are observable only for the IPO firms in the data set. We examine whether investment methods significantly affect the IPO value of biotechnology start-ups. As Gompers (1995) stated, the number of financing rounds, in addition to the size of each investment and total financing provided, is an important measure of the staged investment structure of VC firms. In this paper, we use a proxy for staged financing, which is measured by the number of financing rounds $\left(N_{-} R O U N D\right)$. Data on the number of financing rounds are obtained from the JVR database.

In addition to staged financing, we capture syndication as an investment method.

\footnotetext{
${ }^{24}$ The JASDAQ index was calculated as 100 on December 28, 1991. This index was 55.25 at the end of January 1995 and 104.95 at the end of December 2014. According to the TSE, the number of constituents was 841 at the end of December 2014. Although the TSE provides other indices for emerging markets, such as the J-stock index, only the JASDAQ index was obtainable during the period 1995-2014.

${ }^{25}$ Lerner (1994b) constructed a biotechnology equity index using publicly traded biotechnology firms. Among publicly traded biotechnology firms in Japan, three firms (Medical and Biological Laboratories, Kainos Laboratories, and Precision System Science) were founded before January 1995. Although we could construct the index using these firms, this index did not cover all of the observation period from January 1995 to December 2014 because the earliest of the three firms (Kainos Laboratories) went public in December 1995. Instead of this index, therefore, we used the JASDAQ index in this paper.

${ }^{26}$ Although we may be able to define the cohort dummy for firms founded during the period 2005-2009 (the reference category is the period 2010-2014), as shown in Table 1, none of the firms founded during the period 2010-2014 went public. Therefore, we treated the cohort dummy for firms founded during the period 2005-2014 as the reference category.
} 
Although venture capitalists often invest in a firm through multiple funds and financing rounds, it is not easy to measure the degree of syndication. Meanwhile, as discussed, since the effects of first-round syndication may differ from those of laterround syndication, we measure the first round of financing separate from the later rounds of financing. In this paper, we use the variable for syndication in the first round of financing based on the number of first-round VC firms $\left(N_{-} V C F\right) .{ }^{27}$ The use of this variable may mitigate causality issues caused by the fact that VC firms have an incentive to participate in investments in pre-IPO firms to better their reputations. Additionally, we define the variable for syndication in the later rounds of financing by the number of later-round VC firms $\left(N_{-} V C L\right)$. This variable is used to investigate the effects of later-round syndication, compared with those of first-round syndication. Data on the number of VC firms are obtained from the JVR database.

Moreover, the IPO duration is also included in the estimation regression to identify whether this variable has a significant impact on the IPO value. We define the variable for the IPO duration (IPO_DUR) as the logarithm of the months from the foundation date to the IPO date. Furthermore, we use the variable for the JASDAQ index $(J I N D E X)$ to control for market conditions in the estimation egression of the IPO value. Note that this variable is measured at the time of the firm's IPO in the estimation regression of the IPO value, while it is measured as time variant in the estimation regression of the IPO duration.

Table 8 summarizes the definitions of the variables and Table 9 shows the summary statistics of the variables used in our analysis.

\footnotetext{
${ }^{27}$ More precisely, we defined this variable as the logarithm of the number of VC firms plus one because only a few firms were not backed by VC firms through the first round of financing.
} 


\section{Estimation results}

\subsection{Results for the IPO duration}

In Table 10, we present the estimation results for the IPO duration using the competing-risks regression. While 33 firms among 213 firms in the data set have experienced an IPO during the observation period, 36 firms have exited the market before going public, mainly because of liquidation, and these cases are regarded as competing risks in this paper. When considering exits other than IPOs as competing risks, we estimate the determinants of the IPO duration using the competing risks regression. Table 10 provides both the estimated coefficients and sub-hazard ratios. While the variables for initial VC financing $\left(V C_{-} S T\right)$, university origin $(U N I V)$, spin-off $(S P I N O F F)$, market conditions (JINDEX), cohort dummies (C95_99 and C00_04), and industry dummies (DRUG and HEALTH) are used in column (i), we omit the industry dummies in column (ii) because they are insignificant. ${ }^{28}$

As shown in Table 10, the coefficients of $V C_{-} S T$ are positive at the $1 \%$ significance level and the sub-hazard ratio for initially VC-backed start-ups is approximately three times higher than that for other counterparts. The results reveal that biotechnology start-ups initially backed by VC firms are more likely to go public within a shorter period, which is consistent with Lee and Lee (2008). Although information asymmetries are severe when biotechnology start-ups start their businesses, some VC firms commit to start-up financing in the biotechnology industry of Japan. In general, venture capitalists are required to not only screen and judge viable businesses but also recoup their investments in the firms. The findings suggest that VC firms that have committed to start-up financing are more likely to induce the IPO of biotechnology start-ups within a shorter period.

The coefficients of $U N I V$ are also positive at the $1 \%$ significance level and the

\footnotetext{
${ }^{28}$ We also estimated the determinants of exits using the standard proportional hazards model and the competing risks regression when considering IPOs as competing risks. However, we did not find any significant results for these variables.
} 
sub-hazard ratio for university-origin start-ups is approximately six times higher than that for other counterparts. We find that the likelihood of an IPO for universityorigin start-ups differs from that of other counterparts in the biotechnology industry of Japan. The results reveal that biotechnology start-ups originating from universities are more likely to go public within a shorter period. The findings suggest that university-origin start-ups have more incentive to access equity markets quickly, presumably to sustain financing for their R\&D activities. This may also imply that universities tend to select and commercialize technologies that they expect can be given a highly positive evaluation in equity markets.

In addition, the coefficients of SPINOFF are positive at the $5 \%$ significance level. We find that the likelihood of an IPO for spin-off start-ups differs from that of other counterparts in the biotechnology industry. The results reveal that spin-offs in the biotechnology industry are more likely to go public within a shorter period. These findings indicate that the IPO of biotechnology start-ups depends on initial involvement.

Moreover, the coefficients of $J I N D E X$ are insignificant, indicating that the IPO duration is not significantly affected by market conditions. The results suggest that the timing of IPOs does not depend on market conditions. Our findings are inconsistent with Lerner (1994b) who found that a higher level of the equity index increases the probability of an IPO. For biotechnology start-ups, financing is often critical for R\&D activities. At the same time, many biotechnology start-ups have negative profits; therefore, these firms cannot rely on internal financing for $\mathrm{R} \& \mathrm{D}$ activities. Even if a firm predicts that the market value of equity will be evaluated lower, the firm may be forced to access capital markets for R\&D. Additionally, VC firms have an incentive to recoup their investments sooner, unless they are cash-rich. The findings suggest that biotechnology start-ups cannot afford to wait for a higher market value to continue their $R \& D$ activities.

Furthermore, the coefficients of $C 95 \_99$ are positive at the $1 \%$ significance level, 
while those of $C 00 \_04$ are insignificant. The results indicate that biotechnology start-ups founded in the late 1990s are more likely to go public within a shorter period. In the early periods of the rise in emerging markets, the IPO of biotechnology start-ups may be readily acceptable due to the policies promoting start-ups from universities.

\subsection{Results for the IPO value}

In Table 11, we present the estimation results for the IPO value, which is defined as the logarithm of the market value of equity $(M V)$, using the Heckman selection model. ${ }^{29}$ While the variables for initial VC financing $\left(V C_{-} S T\right)$, university origin $(U N I V)$, spin-off (SPINOFF), and cohort dummies (C95_99 and C00_04) are used for the selection equation, the variables for staged financing $\left(N_{-} R O U N D\right)$ and first-round syndication $\left(N_{-} V C F\right)$, in addition to market conditions (JINDEX), are used to investigate whether investment methods affect the IPO value. For comparison, the variable for later-round syndication $\left(N_{-} V C L\right)$ is used instead of $N_{-} V C F$. Moreover, the variable for the IPO duration $\left(I P O \_D U R\right)$ is used to investigate whether the IPO value depends on the IPO duration. First, to identify the effects of initial VC financing on the IPO value, we use $V C_{-} S T$ in column (i). Because $N_{-} R O U N D, N_{-} V C F, N_{-} V C L$, and $I P O_{-} D U R$ are correlated with one another, we use each of these variables in columns (ii) to (v), respectively. ${ }^{30}$ In Table 12 , we present the estimation results for the relative IPO value, which is defined as the ratio of the IPO value to total equity invested $\left(R_{-} M V\right)$.

As shown in Tables 11 and 12, the coefficients of $V C_{-} S T$ are positive but insignificant. We find little evidence that the IPO value of biotechnology start-ups depend on the initial involvement of VC firms. While biotechnology start-ups ini-

\footnotetext{
${ }^{29}$ We also used an ordinary least squares method and the results were similar to those using the Heckman selection model. Therefore, we report only the results using the Heckman selection model.

${ }^{30}$ For instance, the correlation coefficients between $N_{-} R O U N D$ and $N_{-} V C L$, between $N_{-} R O U N D$ and $I P O \_D U R$, and between $N_{-} V C L$ and $I P O \_D U R$ were $0.684,0.700$, and 0.476 , respectively.
} 
tially backed by VC firms are more likely to go public within a shorter period, they are not highly evaluated in the market.

With respect to staged financing, the coefficients of $N_{-} R O U N D$ are negative and significant in Tables 11 and 12. The results reveal that the number of financing rounds has a negative impact not only on the IPO value but also on the relative IPO value. We find little evidence that the returns to more staged financing are higher than those to less staged financing, which is inconsistent with Gompers (1995). The findings suggest that staged capital infusion does not create any additional value. In contrast, there is the possibility that staged capital infusion induces a negative signal about the value of a project.

With respect to syndication, the coefficients of $N_{-} V C F$ are insignificant in Table 11, while they are negative in Table 12 . We do not find that the number of VC firms has a positive effect on the IPO value or the relative IPO value. This indicates that syndication does not increase the market value of equity, even though it induces a large amount of capital. We find little evidence that the returns of more syndicated investments are higher than those of less syndicated investments, which is inconsistent with Lerner (1994a). In contrast, the coefficients of $N_{-} V C L$ are negative and significant in Tables 11 and 12. When syndication is measured by the number of VC firms in the later rounds of financing, we find a negative effect of syndication on the IPO value. The results indicate that syndication in the later rounds of financing, rather than in the first round of financing, has a more negative impact on the IPO value; thus suggesting that as Lerner emphasized, the effects of syndication differ between the first and later rounds of financing. Several studies have found imitative and herd behavior for Japanese firms and banks (e.g., Lieberman and Asaba, 2006; Uchida and Nakagawa, 2007). In the later rounds of financing for pre-IPO firms, VC firms have more incentive to participate in investments to better their reputations. As a result, they simply herd together. Given that syndication in the later-rounds is due to herd behavior, such syndication through staged financing does not provide 
opportunities to improve firm values, and this may rather impede the enhancement of market values at the IPO.

In column (v) of Tables 11 and 12, the coefficients of IPO_DUR are negative and significant, which indicates that the IPO duration has a negative effect on the IPO value. The results show that IPOs with a shorter period are highly evaluated in the market among biotechnology start-ups. While Lee and Lee (2008) found that there is no special relationship between IPO time and IPO value in the stock market, we find a negative relationship between them. Our findings suggest that a delayed IPO does not guarantee a higher value, which implies that start-ups in the biotechnology industry should go public quickly. As the period in which new technologies can make large profits is restricted because of the patent protection period, IPOs with a longer period may not be highly evaluated in the market.

Furthermore, the coefficients of JINDEX are positive in Tables 11 and 12, although JINDEX does not have a sufficiently significant effect on the relative IPO value in Table 12. We find that the market value of equity tends to depend on market conditions at the IPO. The results indicate that the stock market boom leads to a higher market value of equity in the biotechnology industry of Japan. ${ }^{31}$ As shown in Table 10, while the timing of IPOs for biotechnology start-ups does not depend on market conditions, the market value of equity at the IPO tends to depend on market conditions.

\section{Conclusions}

This paper explored the IPO and financing of biotechnology start-ups in Japan. Using a unique data set, we found that biotechnology start-ups initially backed by VC firms and those originating from universities are more likely to go public within a shorter period. We also examined whether the two investment methods used by VC

\footnotetext{
${ }^{31}$ As a typical case, the stock prices of biotechnology firms rose sharply after the announcement of the 2012 Nobel Prize in Physiology or Medicine by John B. Gurdon and Shinya Yamanaka.
} 
firms affect the market value of equity at the IPO. The results revealed that staged financing and syndication do not create a higher value of biotechnology start-ups at the IPO. Furthermore, we provided evidence that the timing of IPOs does not depend on market conditions in the biotechnology industry, whereas the market value of equity tends to depend on market conditions.

This paper makes several contributions to the literature. The results indicate that the return on investment for biotechnology start-ups in Japan is approximately seven times greater, on average, than the invested amount when the start-ups issue an IPO. Moreover, our findings suggest that biotechnology start-ups with capital raised by staged financing are negatively evaluated in the market and syndication does not result in higher values, indicating that the investment methods do not create a higher value of biotechnology start-ups at the IPO. Furthermore, we employ an analytical method to examine the IPO duration and estimate the determinants of the IPO duration, while taking into account competing risks alternative to the IPO. In addition, we propose that the relative IPO value, instead of simply using the market value of equity, is a more suitable proxy to evaluate the IPO value and provide more reliable results for the determinants of the IPO values.

This paper also includes several implications. Biotechnology start-ups - specifically, initially VC-backed ones - are more likely to go public within a shorter period, regardless of market conditions. This is partly because the access to equity markets through an IPO becomes imperative for biotechnology start-ups to secure financing for their R\&D activities. At the same time, this indicates that $\mathrm{VC}$ firms promote the firms' IPOs to recoup their investments sooner. However, we provide empirical evidence on the negative impact of investment methods on the market values at the IPO in the biotechnology industry of Japan. Even though venture capitalists can reduce their investment risks through various investment methods, such methods can actually constrain the efficient investment in high-tech start-ups. Whereas VC firms are often expected to provide hands-on management support, they may give 
priority to recovering their investments rather than adding value to biotechnology start-ups. In fact, some VC firms, instead of individual investors, provide the initial capital for the R\&D activities of biotechnology start-ups in the early stages in Japan. In this respect, complementary financial support systems for $R \& D$ activities are required to prevent biotechnology start-ups from going public under unfavorable market conditions. ${ }^{32}$ Meanwhile, as already discussed, Japan has the characteristics of a bank-centered capital market. VC firms in Japan may have less incentive to take large risks, thereby resulting in an increase in the number of $\mathrm{VC}$ firms that imitate investment behavior. ${ }^{33}$ In this respect, it is hoped that the risk capital of VC firms will have better success in its ability to add value to biotechnology start-ups.

\section{References}

Black, B. S., Gilson, R. J., 1998. Venture capital and the structure of capital markets: banks versus stock markets. Journal of Financial Economics 47, $243-277$.

Brander, J. A., Amit, R., Antweiler, W., 2002. Venture-capital syndication: improved venture selection vs. the value-added hypothesis. Journal of Economics and Management Strategy 11, 423-452.

Cox, D. R., 1972. Regression models and life-tables (with discussion). Journal of the Royal Statistical Society, Series B 34, 187-220.

Deeds, D. L., Decarolis, D., Coombs, J. E., 1997. The impact of firm-specific capabilities on the amount of capital raised in an initial public offering: evidence

\footnotetext{
${ }^{32}$ In the data set, a few firms received subsidies from public research foundations, such as New Energy and Industrial Technology Development Organization (NEDO), and audit corporations. Although we examined their effects on the IPO value, we did not obtain significant results.

${ }^{33}$ Motohashi (2012) argued that the business model in the biotechnology industry of Japan differs from that of the US and such differences can be explained by differences in the venture capital markets between Japan and the US.
} 
from the biotechnology industry. Journal of Business Venturing 12, 31-46.

Fine, J. P., Gray, R. J., 1999. A proportional hazards model for the subdistribution of a competing risk. Journal of the American Statistical Association 94, 496509.

Giot, P., Schwienbacher, A., 2007. IPOs, trade sales and liquidations: modelling venture capital exits using survival analysis. Journal of Banking and Finance $31,679-702$.

Gompers, P. A., 1995. Optimal investment, monitoring, and the staging of venture capital. Journal of Finance 50, 1461-1489.

Goto, A., 2000. Japan's national innovation system: current status and problems. Oxford Review of Economic Policy 16, 103-113.

Hand, J. R. M., 2007. Determinants of the round-to-round returns to pre-IPO venture capital investments in U.S. biotechnology companies. Journal of Business Venturing 22, 1-28.

Heckman, J. J., 1979. Sample selection bias as a specification error. Econometrica $47,153-161$.

Helwege, J., Packer, F., 2004. Initial public offerings in hot and cold markets. Journal of Financial and Quantitative Analysis 39, 541-569.

Helwege, J., Packer, F., 2009. Private matters. Journal of Financial Intermediation $18,362-383$.

Honjo, Y., 2012. Initial public offerings of start-up firms: evidence from Japan. Unpublished paper (presented at 2012 Autumn Meeting of Japanese Economic Association). 
Honjo, Y., 2015. Why are entrepreneurship levels so low in Japan? Japan and the World Economy (forthcoming).

Honjo, Y., Nagaoka, S., Nakamura, K., Shimizu, Y., 2014. Bio-venture no kagakuteki gensen to seicho ni muketeno kadai: "2012 nen Bio-venture Tokei Chosa" ni Motozuite (Scientific sources of bio-ventures and issues toward their growth: a report from "the 2012 Survey on Bio-ventures), IIR Working Paper, WP\#13-22, Hitotsubashi University (in Japanese).

Ibbotson, R. G., Jaffe, J. F., 1975. "Hot issue" markets. Journal of Finance 30, 1027-1042.

Kneller, R., 2003. Autarkic drug discovery in Japanese pharmaceutical companies: insights into national differences in industrial innovation. Research Policy 32, $1805-1827$.

Lee, Y.-J., Lee, J.-D., 2008. Strategy of start-ups for IPO timing across high technology industries. Applied Economics Letters 15, 869-877.

Lerner, J., 1994a. The syndication of venture capital investments. Financial Management 23, 16-27.

Lerner, J., 1994b. Venture capitalists and the decision to go public. Journal of Financial Economics 35, 293-316.

Lieberman, M. B., Asaba, S., 2006. Why do firms imitate each other? Academy of Management Review 31, 366-385.

Megginson, W., Weiss, K., 1991. Venture capitalist certification in initial public offerings. Journal of Finance 46, 879-903.

Miyakawa, D., Takizawa, M., 2013. Performance of newly listed firms: evidence from Japanese firm and venture capital data. RIETI Discussion Paper Series, 13-E-019, Research Institute of Economy, Trade and Industry. 
Motohashi, K., 2012. A comparative analysis of biotechnology startups between Japan and the US. Social Science Japan Journal 15, 219-237.

Nelson, T., 2003. The persistence of founder influence: effects at initial public offering. Strategic Management Journal 24, 707-724.

Pagano, M., Panetta, F., Zingales, L., 1998. Why do companies go public? An empirical analysis. Journal of Finance 53, 27-64.

Ritter, J. R., 1984. The "hot issue" market of 1980. Journal of Business 57, $215-240$.

Uchida, H., Nakagawa, R., 2007. Herd behavior in the Japanese loan market: evidence from bank panel data. Journal of Financial Intermediation 16, 555583. 
Table 1. Distribution of biotechnology start-ups: foundation year

\begin{tabular}{crrrr}
\hline Foundation year & IPO $(A)$ & Non-IPO $(B)$ & Total $(A+B)$ & Ratio $(A /(A+B))$ \\
\hline 1995 & 1 & 2 & 3 & 0.333 \\
1996 & 1 & 0 & 1 & 1.000 \\
1997 & 1 & 1 & 2 & 0.500 \\
1998 & 1 & 2 & 3 & 0.333 \\
1999 & 5 & 8 & 13 & 0.385 \\
2000 & 2 & 17 & 19 & 0.105 \\
2001 & 5 & 16 & 21 & 0.238 \\
2002 & 3 & 17 & 20 & 0.150 \\
2003 & 5 & 20 & 25 & 0.200 \\
2004 & 4 & 22 & 26 & 0.154 \\
2005 & 3 & 12 & 15 & 0.200 \\
2006 & 1 & 19 & 20 & 0.050 \\
2007 & 0 & 10 & 10 & 0.000 \\
2008 & 1 & 2 & 3 & 0.333 \\
2009 & 0 & 4 & 4 & 0.000 \\
2010 & 0 & 8 & 8 & 0.000 \\
2011 & 0 & 8 & 8 & 0.000 \\
2012 & 0 & 4 & 4 & 0.000 \\
2013 & 0 & 6 & 6 & 0.000 \\
2014 & 0 & 2 & 2 & 0.000 \\
\hline Total (over time $)$ & 33 & 180 & 213 & 0.155 \\
\hline
\end{tabular}

Notes: "IPO" and "Non-IPO" represent biotechnology start-ups that have experienced or not experienced an IPO by December 2014, respectively. 
Table 2. Summary statistics of IPO duration

\begin{tabular}{lcccrrr}
\hline \multicolumn{1}{c}{ Class } & Mean & S.D. & $25 \%$ & Median & $75 \%$ & $N$ \\
\hline $\begin{array}{l}\text { IPO duration } \\
\text { (Foundation year) }\end{array}$ & & & & & & \\
1995-1999 & 88.1 & 35.9 & 59.0 & 96.0 & 106.0 & 9 \\
$2000-2004$ & 85.9 & 41.4 & 43.0 & 104.0 & 124.0 & 19 \\
$2005-2009$ & 74.6 & 19.1 & 79.0 & 82.0 & 83.0 & 5 \\
\hline All & 84.8 & 36.8 & 57.0 & 88.0 & 116.0 & 33 \\
\hline
\end{tabular}

Notes: "IPO duration" represents the number of months from the foundation date to the IPO date. S.D. indicates standard deviation. $N$ indicates the number of firms.

Table 3. Distribution of biotechnology start-ups: IPO/Non-IPO and initially VC-backed

\begin{tabular}{lrrr}
\hline IPO/Non-IPO & Initially VC-backed $(A)$ & Others $(B)$ & Total $(A+B)$ \\
\hline IPO $(C)$ & 7 & 26 & 33 \\
Non-IPO $(D)$ & 10 & 170 & 180 \\
Total $(C+D)$ & 17 & 196 & 213 \\
\hline$\chi^{2}=9.308(p<0.01)$ & & & \\
\hline
\end{tabular}

Notes: "Initially VC-backed" represents biotechnology start-ups that raised equity from VC firms when they were founded. "IPO" and "Non-IPO" represent biotechnology start-ups that have experienced or not experienced an IPO by December 2014, respectively. 
Table 4. Distribution of biotechnology start-ups: IPO/Non-IPO and university origin

\begin{tabular}{lrrr}
\hline IPO/Non-IPO & University-origin $(A)$ & Others $(B)$ & Total $(A+B)$ \\
\hline IPO $(C)$ & 23 & 10 & 33 \\
Non-IPO $(D)$ & 60 & 120 & 180 \\
Total $(C+D)$ & 83 & 130 & 213 \\
\hline$\chi^{2}=15.505(p<0.01)$ & & & \\
\hline
\end{tabular}

Notes: "Initially VC-backed" represents biotechnology start-ups that raised equity from VC firms when they were founded. "University-origin" represents biotechnology start-ups that originated from universities. "IPO" and "Non-IPO" represent biotechnology start-ups that have experienced or not experienced an IPO by December 2014, respectively.

Table 5. Market value and financing of equity for IPO firms

\begin{tabular}{lrrrrrr}
\hline \multicolumn{1}{c}{ Variable } & \multicolumn{1}{c}{ Mean } & \multicolumn{1}{c}{ S.D. } & \multicolumn{1}{c}{$25 \%$} & Median & \multicolumn{1}{c}{$75 \%$} & $N$ \\
\hline IPO value $(A)$ & 28,621 & 38,029 & 8,032 & 13,978 & 23,660 & 32 \\
Equity financing $(B)$ & 3,601 & 5,003 & 837 & 1,751 & 4,687 & 32 \\
IPO capital increase $(C)$ & 2,359 & 1,873 & 819 & 2,100 & 2,942 & 32 \\
\hline$A / B$ & 57.83 & 182.66 & 1.77 & 6.16 & 23.03 & 32 \\
$A /(B+C)$ & 7.15 & 10.33 & 1.28 & 3.05 & 7.08 & 32 \\
\hline
\end{tabular}

Notes: "IPO value" represents the market value of equity (million yen), based on the firstday closing price. "Equity financing" represents invested equity defined as the sum of paid-in capital, additional paid-in capital, and capital reduction (million yen) prior to the IPO. "IPO capital increase" represents the capital increase (million yen) at the IPO. 
Table 6. Number of financing rounds and VC firms

\begin{tabular}{lrrrrrr}
\hline \multicolumn{1}{c}{ Variable } & Mean & S.D. & $25 \%$ & Median & $75 \%$ & $N$ \\
\hline Number of financing rounds & 4.88 & 2.61 & 3.00 & 5.00 & 6.50 & 32 \\
Number of VC firms & 14.31 & 8.44 & 9.00 & 12.50 & 19.00 & 32 \\
Number of first-round VC firms & 3.31 & 3.59 & 1.00 & 2.00 & 4.50 & 32 \\
\hline
\end{tabular}

Notes: S.D. indicates standard deviation. $N$ indicates the number of firms.

Table 7. Market value and financing of equity for IPO firms by the numbers of rounds and first-round VC firms.

\begin{tabular}{|c|c|c|c|c|c|c|}
\hline Variable / Type & Mean & S.D. & $25 \%$ & Median & $75 \%$ & $N$ \\
\hline \multirow{2}{*}{\multicolumn{7}{|c|}{$\begin{array}{l}\text { IPO value } \\
\text { (Number of financing rounds) }\end{array}$}} \\
\hline & & & & & & \\
\hline 1-3 rounds & 48,80 & 44,485 & 14,644 & 32,804 & 78,877 & 11 \\
\hline 4-7 rounds & 20,038 & 33,608 & 7,455 & 10,467 & 17,408 & 17 \\
\hline $8+$ rounds & 11,036 & 8,765 & 5,817 & 8,794 & 16,255 & 4 \\
\hline \multicolumn{7}{|c|}{ (Number of first-round VC firms) } \\
\hline $0-3 \mathrm{VC}$ firms & 35,667 & 45,569 & 7,140 & 16,026 & 41,152 & 20 \\
\hline 4-7 VC firms & 10,296 & 4,661 & 7,349 & 10,41 & 12,965 & 8 \\
\hline $8+$ VC firms & 30,039 & 22,651 & 13,545 & 26,220 & 46,532 & 4 \\
\hline \multirow{2}{*}{\multicolumn{7}{|c|}{$\begin{array}{l}\text { IPO value/(Equity financing + IPO capital increase) } \\
\text { (Number of financing rounds) }\end{array}$}} \\
\hline & & & & & & \\
\hline 1-3 rounds & 10.31 & 9.71 & 1.76 & 7.16 & 17.94 & 11 \\
\hline 4-7 rounds & 6.36 & 11.51 & 1.74 & 2.51 & 6.05 & 17 \\
\hline $8+$ rounds & 1.87 & 1.87 & 0.82 & 1.06 & 2.93 & 6 \\
\hline \multicolumn{7}{|c|}{ (Number of first-round VC firms) } \\
\hline 0-3 VC firms & 9.47 & 12.46 & 1.28 & 4.29 & 13.17 & 20 \\
\hline 4-7 VC firms & 3.52 & 2.49 & 1.83 & 2.26 & 6.25 & 8 \\
\hline $8+\mathrm{VC}$ firms & 2.85 & 2.98 & 1.17 & 1.47 & 4.53 & 4 \\
\hline
\end{tabular}

Notes: "IPO value" represents the market value of equity (million yen), based on the firstday closing price. "Equity financing" represents total equity invested, defined as the sum of paid-in capital, additional paid-in capital, and capital reduction (million yen) prior to the IPO. "IPO capital increase" represents the capital increase (million yen) at the IPO. 
Table 8. Variable definitions

\begin{tabular}{|c|c|c|}
\hline Variable & Symbol & Definition \\
\hline \multicolumn{3}{|l|}{ (All firms) } \\
\hline Initial VC financing & $V C \_S T$ & $\begin{array}{l}\text { Dummy variable for the firm financed by a VC } \\
\text { firm when the firm was founded. }\end{array}$ \\
\hline University origin & $U N I V$ & $\begin{array}{l}\text { Dummy variable for the firm related to a uni- } \\
\text { versity when the firm started a business fulfill- } \\
\text { ing any of the following conditions: (1) the firm } \\
\text { was founded, based on technologies originating } \\
\text { from a university, (2) the firm conducted joint } \\
\text { research with a university within one year, ( } 3 \text { ) } \\
\text { the firm was founded with support of a univer- } \\
\text { sity, (4) the firm or a trusted organization itself } \\
\text { proclaimed university origin. }\end{array}$ \\
\hline Spin-off & SPINOFF & Dummy variables for the subsidiary firm. \\
\hline Market conditions & $J I N D E X$ & $\begin{array}{l}\text { JASDAQ index based on the month-end closing } \\
\text { price, normalized by its value in January } 1991 \\
(=100) \text {. }\end{array}$ \\
\hline \multirow[t]{2}{*}{ Cohort dummies } & C95_99 & $\begin{array}{l}\text { Dummy variable for the firm founded during the } \\
\text { period } 1995-1999 \text {. }\end{array}$ \\
\hline & C00_04 & $\begin{array}{l}\text { Dummy variable for the firm founded during the } \\
\text { period } 2000-2004 \text {. }\end{array}$ \\
\hline \multirow[t]{2}{*}{ Industry dummies } & $I_{-} D R U G$ & Dummy variable for the firm in drug discovery. \\
\hline & $I_{-} H E A L T H$ & $\begin{array}{l}\text { Dummy variable for the firm in medical and } \\
\text { health care, except for drug discovery. }\end{array}$ \\
\hline \multicolumn{3}{|l|}{ (Only for IPO firms) } \\
\hline IPO value & $M V$ & $\begin{array}{l}\text { Logarithm of the market value of equity (million } \\
\text { yen), based on the first-day closing price. }\end{array}$ \\
\hline Relative IPO value & $R_{-} M V$ & $\begin{array}{l}\text { Logarithm of the ratio of the market value of eq- } \\
\text { uity, based on the first-day closing price, divided } \\
\text { by the sum of paid-in capital, additional paid-in } \\
\text { capital, and capital reduction prior to the IPO } \\
\text { plus capital increase at the IPO. }\end{array}$ \\
\hline Staged financing & $N_{-} R O U N D$ & $\begin{array}{l}\text { Logarithm of the number of financing rounds by } \\
\text { VC firms and corporations prior to the IPO. }\end{array}$ \\
\hline \multirow[t]{2}{*}{ Syndication } & $N_{-} V C F$ & $\begin{array}{l}\text { Logarithm of the number of } \mathrm{VC} \text { firms investing } \\
\text { in the firm from the foundation date through the } \\
\text { first round of financing plus one. }\end{array}$ \\
\hline & $N_{-} V C L$ & $\begin{array}{l}\text { Logarithm of the number of } \mathrm{VC} \text { firms investing } \\
\text { in the firm after the first round of financing prior } \\
\text { to the IPO plus one. }\end{array}$ \\
\hline IPO duration & $I P O \_D U R$ & $\begin{array}{l}\text { Logarithm of the number of months from the } \\
\text { foundation date to the IPO date. }\end{array}$ \\
\hline
\end{tabular}

Note: All the dummy variables take the value of one if the stated condition holds, and zero otherwise. 
Table 9. Summary statistics of variables

\begin{tabular}{|c|c|c|c|c|c|c|}
\hline Variable & Mean & S.D. & $25 \%$ & Median & $75 \%$ & $N$ \\
\hline \multicolumn{7}{|l|}{ (All firms) } \\
\hline$V C \_S T$ & 0.080 & - & - & - & - & 213 \\
\hline$U N I V$ & 0.390 & - & - & - & - & 213 \\
\hline SPINOFF & 0.066 & - & - & - & - & 213 \\
\hline$J I N D E X$ & 72.063 & 23.807 & 50.490 & 65.020 & 95.490 & 24,927 \\
\hline C95_99 & 0.103 & - & - & - & - & 213 \\
\hline C00_04 & 0.521 & - & - & - & - & 213 \\
\hline$I_{-} D R U G$ & 0.385 & - & - & - & - & 213 \\
\hline I_HEALTH & 0.183 & - & - & - & - & 213 \\
\hline \multicolumn{7}{|l|}{ (IPO firms) } \\
\hline$M V$ & 9.654 & 1.065 & 8.989 & 9.544 & 10.184 & 32 \\
\hline$R \_M V$ & 1.282 & 1.145 & 0.242 & 1.114 & 1.957 & 32 \\
\hline$V C \_S T$ & 0.219 & - & - & - & - & 32 \\
\hline$N \_R O U N D$ & 1.428 & 0.604 & 1.099 & 1.609 & 1.869 & 32 \\
\hline$N_{-} V C F$ & 1.178 & 0.757 & 0.693 & 1.099 & 1.701 & 32 \\
\hline$N_{-} V C L$ & 2.102 & 1.016 & 1.386 & 2.350 & 2.917 & 32 \\
\hline$I P O \_D U R$ & 4.309 & 0.542 & 4.034 & 4.448 & 4.758 & 32 \\
\hline$J I N D E X$ & 68.713 & 20.298 & 50.825 & 66.775 & 86.830 & 32 \\
\hline
\end{tabular}

Notes: S.D. indicates standard deviation. $N$ indicates the number of firms. For all firms, $J I N D E X$ is time variant and the others are time invariant. 
Table 10. Estimation results for the IPO duration

\begin{tabular}{|c|c|c|c|c|}
\hline \multirow[b]{2}{*}{ Variable } & \multicolumn{2}{|c|}{ (i) } & \multicolumn{2}{|c|}{ (ii) } \\
\hline & Coef. & SHR & Coef. & SHR \\
\hline$V C_{-} S T_{i}$ & $\begin{array}{c}1.164^{* * *} \\
(0.417)\end{array}$ & $\begin{array}{c}3.203^{* * *} \\
(1.331)\end{array}$ & $\begin{array}{c}1.117^{* * *} \\
(0.388)\end{array}$ & $\begin{array}{c}3.056^{* * *} \\
(1.185)\end{array}$ \\
\hline$U N I V_{i}$ & $\begin{array}{c}1.770^{* * *} \\
(0.448)\end{array}$ & $\begin{array}{c}5.869^{* * *} \\
(2.629)\end{array}$ & $\begin{array}{c}1.803^{* * *} \\
(0.432)\end{array}$ & $\begin{array}{c}6.067^{* * *} \\
(2.623)\end{array}$ \\
\hline SPINOFF $F_{i}$ & $\begin{array}{l}1.936^{* *} \\
(0.756)\end{array}$ & $\begin{array}{l}6.928^{* *} \\
(5.240)\end{array}$ & $\begin{array}{l}1.928^{* *} \\
(0.755)\end{array}$ & $\begin{array}{l}6.878^{* *} \\
(5.195)\end{array}$ \\
\hline$J I N D E X_{i t}$ & $\begin{array}{c}-0.004 \\
(0.006)\end{array}$ & $\begin{array}{c}0.996 \\
(0.006)\end{array}$ & $\begin{array}{l}-0.005 \\
(0.006)\end{array}$ & $\begin{array}{c}0.995 \\
(0.006)\end{array}$ \\
\hline$C 95 \_99_{i}$ & $\begin{array}{c}1.841^{* * *} \\
(0.610)\end{array}$ & $\begin{array}{c}6.303^{* * *} \\
(3.844)\end{array}$ & $\begin{array}{c}1.720^{* * *} \\
(0.553)\end{array}$ & $\begin{array}{c}5.582^{* * *} \\
(3.087)\end{array}$ \\
\hline$C 00 \_04_{i}$ & $\begin{array}{c}0.504 \\
(0.528)\end{array}$ & $\begin{array}{l}1.655 \\
(0.874)\end{array}$ & $\begin{array}{c}0.506 \\
(0.521)\end{array}$ & $\begin{array}{l}1.659 \\
(0.864)\end{array}$ \\
\hline$I_{-} D R U G_{i}$ & $\begin{array}{c}0.293 \\
(0.407)\end{array}$ & $\begin{array}{c}1.340 \\
(0.546)\end{array}$ & & \\
\hline$I_{-} H E A L T H_{i}$ & $\begin{array}{l}-0.117 \\
(0.555)\end{array}$ & $\begin{array}{c}0.889 \\
(0.494)\end{array}$ & & \\
\hline Number of firms & & & & \\
\hline Number of IPOs & & & & \\
\hline Number of competing events & & & & \\
\hline Log pseudo-likelihood & & & & \\
\hline Wald $\chi^{2}$ & & & & \\
\hline
\end{tabular}

Note: Figures in parentheses are standard errors adjusted for 213 firms. "Coef." represents estimated coefficients and "SHR" represents the sub-hazard ratio. ***, ${ }^{* *}$, and * indicate the $1 \%, 5 \%$, and $10 \%$ significance levels, respectively. 
Table 11. Estimation results for the IPO value $(M V)$

\begin{tabular}{|c|c|c|c|c|c|}
\hline Variable & $\begin{array}{l}\text { (i) } \\
\text { Coef. }\end{array}$ & $\begin{array}{l}\text { (ii) } \\
\text { Coef. }\end{array}$ & $\begin{array}{l}\text { (iii) } \\
\text { Coef. }\end{array}$ & $\begin{array}{l}\text { (iv) } \\
\text { Coef. }\end{array}$ & $\begin{array}{l}\text { (v) } \\
\text { Coef. }\end{array}$ \\
\hline$V C_{-} S T_{i}$ & $\begin{array}{c}0.604 \\
(0.455)\end{array}$ & & & & \\
\hline$N_{-} R O U N D_{i}$ & & $\begin{array}{c}-0.741^{* * *} \\
(0.256)\end{array}$ & & & \\
\hline$N_{-} V C F_{i}$ & & & $\begin{array}{c}0.117 \\
(0.225)\end{array}$ & & \\
\hline$N_{-} V C L_{i}$ & & & & $\begin{array}{c}-0.433^{* * *} \\
(0.147)\end{array}$ & \\
\hline$I P O \_D U R_{i}$ & & & & & $\begin{array}{c}-0.828^{* * *} \\
(0.281)\end{array}$ \\
\hline$J I N D E X_{i}$ & $\begin{array}{c}0.025^{* * *} \\
(0.009)\end{array}$ & $\begin{array}{c}0.023^{* * *} \\
(0.008)\end{array}$ & $\begin{array}{c}0.022^{* * *} \\
(0.008)\end{array}$ & $\begin{array}{c}0.020^{* * *} \\
(0.008)\end{array}$ & $\begin{array}{c}0.026^{* * *} \\
(0.008)\end{array}$ \\
\hline Constant term & $\begin{array}{c}7.795^{* * *} \\
(0.984)\end{array}$ & $\begin{array}{c}9.131^{* * *} \\
(0.822)\end{array}$ & $\begin{array}{c}8.376^{* * *} \\
(0.833)\end{array}$ & $\begin{array}{c}9.416^{* * *} \\
(0.816)\end{array}$ & $\begin{array}{c}11.483^{* * *} \\
(1.267)\end{array}$ \\
\hline (Selection) & & & & & \\
\hline$V C_{-} S T_{i}$ & $\begin{array}{l}0.927^{* *} \\
(0.363)\end{array}$ & $\begin{array}{l}0.931^{* *} \\
(0.386)\end{array}$ & $\begin{array}{c}0.989^{* * *} \\
(0.355)\end{array}$ & $\begin{array}{c}0.981^{* * *} \\
(0.365)\end{array}$ & $\begin{array}{l}0.939^{* *} \\
(0.371)\end{array}$ \\
\hline$U N I V_{i}$ & $\begin{array}{c}1.010^{* * *} \\
(0.260)\end{array}$ & $\begin{array}{c}1.010^{* * *} \\
(0.261)\end{array}$ & $\begin{array}{c}1.015^{* * *} \\
(0.258)\end{array}$ & $\begin{array}{c}0.996^{* * *} \\
(0.201)\end{array}$ & $\begin{array}{c}1.007^{* * *} \\
(0.261)\end{array}$ \\
\hline SPINOFF & $\begin{array}{l}1.117^{* *} \\
(0.460)\end{array}$ & $\begin{array}{l}1.117^{* *} \\
(0.460)\end{array}$ & $\begin{array}{l}1.128^{* *} \\
(0.449)\end{array}$ & $\begin{array}{l}1.098^{* *} \\
(0.458)\end{array}$ & $\begin{array}{l}1.111^{* *} \\
(0.460)\end{array}$ \\
\hline C95_99 & $\begin{array}{c}1.546^{* * *} \\
(0.409)\end{array}$ & $\begin{array}{c}1.541^{* * *} \\
(0.416)\end{array}$ & $\begin{array}{c}1.466^{* * *} \\
(0.425)\end{array}$ & $\begin{array}{c}1.512^{* * *} \\
(0.417)\end{array}$ & $\begin{array}{c}1.535^{* * *} \\
(0.413)\end{array}$ \\
\hline$C 00 \_04_{i}$ & $\begin{array}{l}0.698^{* *} \\
(0.301)\end{array}$ & $\begin{array}{l}0.696^{* *} \\
(0.304)\end{array}$ & $\begin{array}{l}0.670^{* *} \\
(0.297)\end{array}$ & $\begin{array}{l}0.702^{* *} \\
(0.299)\end{array}$ & $\begin{array}{l}0.690^{* *} \\
(0.303)\end{array}$ \\
\hline Constant term & $\begin{array}{c}-2.344^{* * *} \\
(0.330)\end{array}$ & $\begin{array}{c}-2.343^{* * *} \\
(0.333)\end{array}$ & $\begin{array}{c}-2.325^{* * *} \\
(0.329)\end{array}$ & $\begin{array}{c}-2.339^{* * *} \\
(0.330)\end{array}$ & $\begin{array}{c}-2.338^{* * *} \\
(0.333)\end{array}$ \\
\hline$\rho$ & 0.020 & -0.016 & -0.320 & -0.212 & -0.057 \\
\hline$\sigma$ & 0.899 & 0.820 & 0.951 & 0.830 & 0.819 \\
\hline$\lambda$ & 0.018 & -0.013 & -0.304 & -0.176 & -0.047 \\
\hline Number of firms & 212 & 212 & 212 & 212 & 212 \\
\hline Number of IPOs & 32 & 32 & 32 & 32 & 32 \\
\hline Log likelihood & -112 & -109 & -113 & -109 & -109 \\
\hline Wald $\chi^{2}$ & $8.33^{* *}$ & $15.9^{* * *}$ & $6.96^{* *}$ & $17.0^{* * *}$ & $16.7^{* * *}$ \\
\hline
\end{tabular}

Note: Figures in parentheses are standard errors. "Coef." represents estimated coefficients. ***, $* *$, and $*$ indicate the $1 \%, 5 \%$, and $10 \%$ significance levels, respectively. 
Table 12. Estimation results for the relative IPO value $\left(R_{-} M V\right)$

\begin{tabular}{|c|c|c|c|c|c|}
\hline Variable & $\begin{array}{l}\text { (i) } \\
\text { Coef. }\end{array}$ & $\begin{array}{l}\text { (ii) } \\
\text { Coef. }\end{array}$ & $\begin{array}{l}\text { (iii) } \\
\text { Coef. }\end{array}$ & $\begin{array}{l}\text { (iv) } \\
\text { Coef. }\end{array}$ & $\begin{array}{l}\text { (v) } \\
\text { Coef. }\end{array}$ \\
\hline$V C_{-} S T_{i}$ & $\begin{array}{c}0.090 \\
(0.539)\end{array}$ & & & & \\
\hline$N_{-} R O U N D_{i}$ & & $\begin{array}{c}-0.681^{* *} \\
(0.274)\end{array}$ & & & \\
\hline$N_{-} V C F_{i}$ & & & $\begin{array}{l}-0.184 \\
(0.247)\end{array}$ & & \\
\hline$N_{-} V C L_{i}$ & & & & $\begin{array}{c}-0.542^{* * *} \\
(0.153)\end{array}$ & \\
\hline$I P O \_D U R_{i}$ & & & & & $\begin{array}{c}-0.667^{* *} \\
(0.325)\end{array}$ \\
\hline$J I N D E X_{i}$ & $\begin{array}{c}0.015 \\
(0.010)\end{array}$ & $\begin{array}{c}0.015 \\
(0.009)\end{array}$ & $\begin{array}{c}0.015 \\
(0.009)\end{array}$ & $\begin{array}{c}0.011 \\
(0.009)\end{array}$ & $\begin{array}{l}0.018^{* *} \\
(0.009)\end{array}$ \\
\hline Constant term & $\begin{array}{l}0.988^{* *} \\
(0.897)\end{array}$ & $\begin{array}{l}1.931^{*} \\
(1.061)\end{array}$ & $\begin{array}{l}1.180 \\
(0.941)\end{array}$ & $\begin{array}{l}2.438^{* *} \\
(1.026)\end{array}$ & $\begin{array}{l}3.459^{* *} \\
(1.454)\end{array}$ \\
\hline (Selection) & & & & & \\
\hline$V C_{-} S T_{i}$ & $\begin{array}{c}0.948^{* * *} \\
(0.358)\end{array}$ & $\begin{array}{c}1.032^{* * *} \\
(0.344)\end{array}$ & $\begin{array}{c}0.960^{* * *} \\
(0.344)\end{array}$ & $\begin{array}{c}1.044^{* * *} \\
(0.338)\end{array}$ & $\begin{array}{c}0.983^{* * *} \\
(0.347)\end{array}$ \\
\hline$U N I V_{i}$ & $\begin{array}{c}1.088^{* * *} \\
(0.252)\end{array}$ & $\begin{array}{c}1.048^{* * *} \\
(0.251)\end{array}$ & $\begin{array}{c}1.070^{* * *} \\
(0.253)\end{array}$ & $\begin{array}{c}1.040^{* * *} \\
(0.249)\end{array}$ & $\begin{array}{c}1.048^{* * *} \\
(0.254)\end{array}$ \\
\hline SPINOFF & $\begin{array}{l}0.963^{* *} \\
(0.499)\end{array}$ & $\begin{array}{c}0.835 \\
(0.545)\end{array}$ & $\begin{array}{l}0.997^{* *} \\
(0.471)\end{array}$ & $\begin{array}{c}0.748 \\
(0.547)\end{array}$ & $\begin{array}{l}0.919^{*} \\
(0.500)\end{array}$ \\
\hline C95_99 & $\begin{array}{c}1.406^{* * *} \\
(0.446)\end{array}$ & $\begin{array}{c}1.392^{* * *} \\
(0.444)\end{array}$ & $\begin{array}{c}1.416^{* * *} \\
(0.428)\end{array}$ & $\begin{array}{c}1.410^{* * *} \\
(0.429)\end{array}$ & $\begin{array}{c}1.447^{* * *} \\
(0.422)\end{array}$ \\
\hline$C 00 \_04_{i}$ & $\begin{array}{l}0.634^{* *} \\
(0.294)\end{array}$ & $\begin{array}{l}0.612^{* *} \\
(0.297)\end{array}$ & $\begin{array}{l}0.641^{* *} \\
(0.291)\end{array}$ & $\begin{array}{l}0.700^{* *} \\
(0.285)\end{array}$ & $\begin{array}{l}0.633^{* *} \\
(0.295)\end{array}$ \\
\hline Constant term & $\begin{array}{c}-2.312^{* * *} \\
(0.330)\end{array}$ & $\begin{array}{c}-2.272^{* * *} \\
(0.338)\end{array}$ & $\begin{array}{c}-2.313^{* * *} \\
(0.327)\end{array}$ & $\begin{array}{c}-2.318^{* * *} \\
(0.328)\end{array}$ & $\begin{array}{c}-2.299^{* * *} \\
(0.330)\end{array}$ \\
\hline$\rho$ & -0.563 & -0.555 & -0.536 & -0.644 & -0.463 \\
\hline$\sigma$ & 1.125 & 1.018 & 1.103 & 0.992 & 1.016 \\
\hline$\lambda$ & -0.633 & -0.565 & -0.591 & -0.639 & -0.471 \\
\hline Number of firms & 212 & 212 & 212 & 212 & 212 \\
\hline Number of IPOs & 32 & 32 & 32 & 32 & 32 \\
\hline Log likelihood & -115 & -113 & -115 & -110 & -114 \\
\hline Wald $\chi^{2}$ & 2.43 & $8.56^{* *}$ & 3.04 & $16.0^{* *}$ & $7.00^{* *}$ \\
\hline
\end{tabular}

Note: Figures in parentheses are standard errors. "Coef." represents estimated coefficients. $* * *, * *$, and $*$ indicate the $1 \%, 5 \%$, and $10 \%$ significance levels, respectively. 


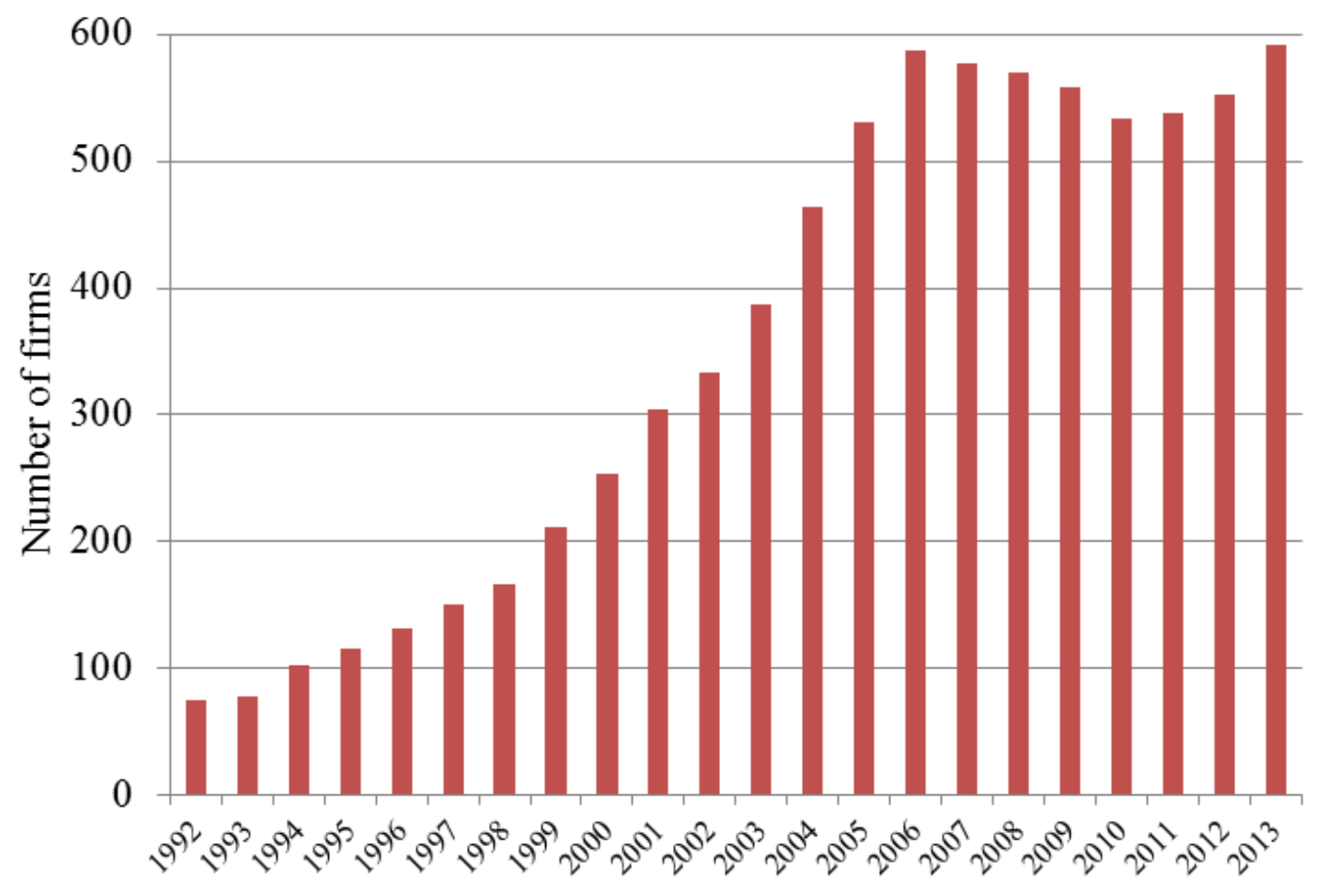

Figure 1. Number of firms in the biotechnology industry of Japan

Source: Japan Biotechnology Association 2014-nen Bio Venture Tokei Doko Chosa Hokokusho (2014 Survey on Bio-Ventures) 


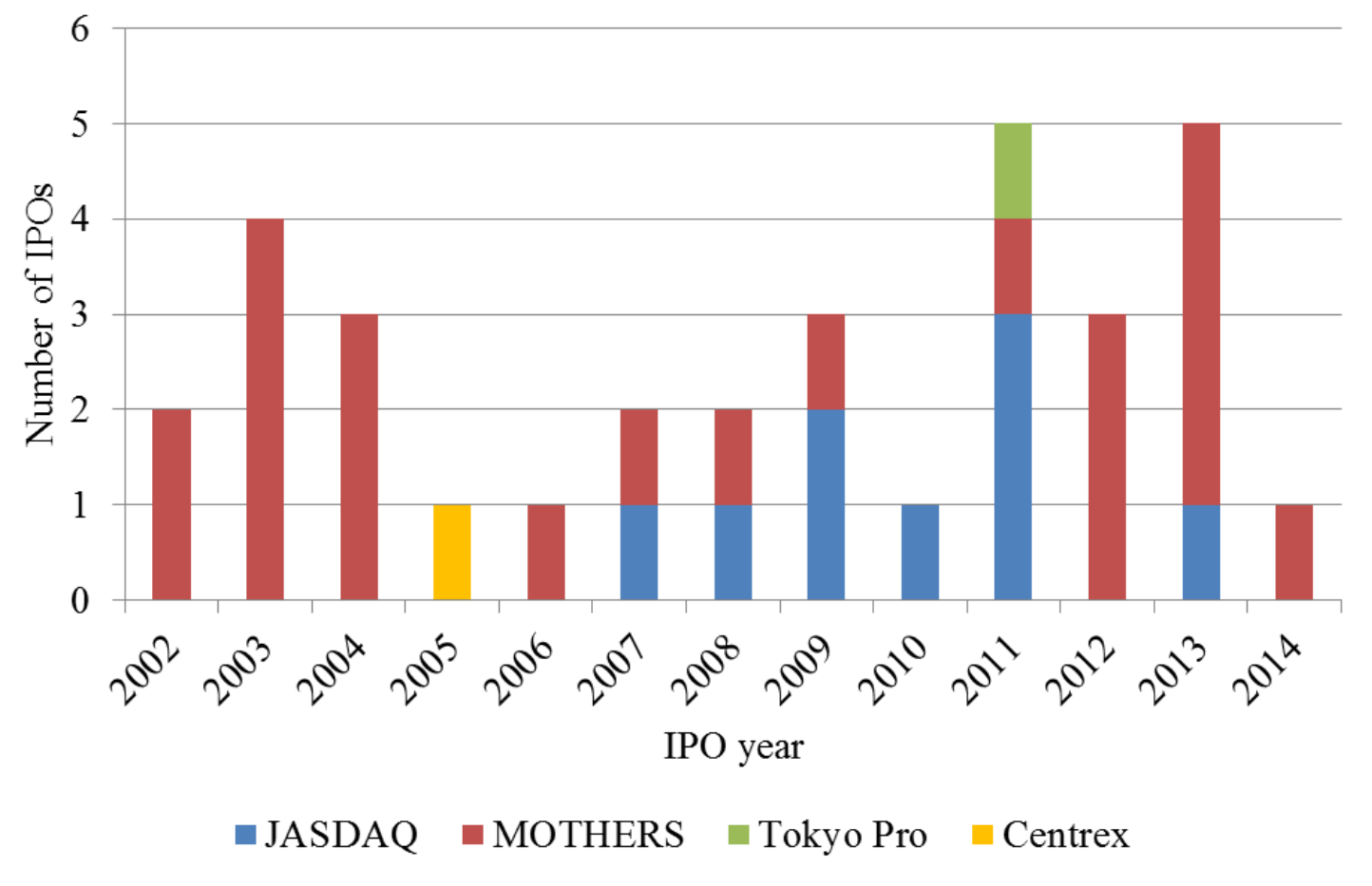

Figure 2. Number of IPOs in the biotechnology industry of Japan

Source: Disclosure Jitsumu Kenkyukai (ed.), Kabusihi Kokai Hakusho (White Paper on Initial Public Offerings)

Note: JASDAQ includes NEO and JASDAQ Growth. Tokyo Pro indicates “Tokyo Pro Market” and includes the former Tokyo AIM. 